\title{
Achene morphology and pericarp anatomy of Anemone Hepatica and Pulsatilla (Anemoninae, Ranunculaceae)
}

Balkrishna Ghimire ( $\sim$ ghimire2ab@gmail.com )

Korea National Arboretum https://orcid.org/0000-0002-2169-1280

Dong Chan Son

Korea National Arboretum

Dabin Yum

Korea National Arboretum

Jae Hyun Kim

Korea National Arboretum

Mi Jin Jeong

Korea National Arboretum

Original Article

Keywords: Anemoninae, Ranunculaceae, achene, pericarp, taxonomy

Posted Date: June 9th, 2020

DOI: https://doi.org/10.21203/rs.3.rs-32226/v1

License: (a) (i) This work is licensed under a Creative Commons Attribution 4.0 International License. Read Full License 


\section{Abstract \\ Background}

Fruit morphological characters have contributing useful taxonomic data and thus used to discriminate the species in different taxonomic rank. The fruit and seed morphology and anatomy in the family Ranunculaceae has been a long history and proved to be a great value for its phylogeny.

\section{Methods}

Achene morphology and pericarp anatomy of 12 taxa representing three genera (Anemone, Hepatica, and Pulsatilla) of tribe Anemoninae were investigated using microtome and light microscopy (LM) to evaluate taxonomic implications of achene characters.

\section{Results}

The achenes of Anemone were elliptical or obovoid and beaked, whereas the achene of Hepatica and Pulsatilla were obovoid and elliptical, respectively. Noticeable variations in both quantitative and qualitative features of achenes were observed among the species of three genera. One-way ANOVA indicated that the quantitative achene variables among the species were highly significant $(P<0.001)$. Pearson's correlation coefficient also showed a significant correlation between different achene variables. The pericarp structure, particularly the number of cell layers and cell form in exocarp and endocarp seems to very useful for species delimitation in Amenome and Hepatica. The nature of endotesta could provide a substantial proof for sub-generic classification in Anemone. The UPGMA analysis also showed the utility of achene features for taxonomic groupings of the species within studied genera.

\section{Conclusion}

Although the sampling specimens represented a limited range of taxa the achene features and pericarp anatomy provide a reasonable source for the taxonomic treatment of studied genera within the tribe.

\section{Background}

The Ranunculaceae comprising 2, 377 accepted species within 65 genera is one of the large basal families within Eudicots (Soltis et al. 2005; Simpson 2006; Heywood et al. 2007; The Plant List 2013). The plants are distributed throughout the world and exhibit wide range of variation in morphological characters, especially in fruit types, and its floral organization (Emadzade et al. 2010). Several classification schemes have been proposed based on the morphological characters, molecular data, and combined morphological and molecular dataset (Hutchinson 1923; Janchen 1949; Johansen and Jansen 1993; Tamura 1995; Jansen et al. 1995; Ro et al. 1997; Wang et al. 2009). On the basis of basic 
chromosome number, and carpel and fruit types Tamura (1995) divided the family into three subfamilies and 11 tribes: Helleboroideae (four tribes), Ranunculoideae (three tribes), and Isopyroideae (four tribes).

Anemoneae is one of the three tribes of subfamily Ranunculoideae traditionally divided into three subtribes: Kinngdoniinae, Anemoninae, and Clematidinae. However, in contemporary classifications based on the morphology and molecular sequence data the subtribe Kingdoniinae with only one species, Kingdonia uniflora Balf. f. \& W.W. Sm., has been excluded from the Anemoneae, even from Ranunculaceae, and treated as its own family Kingdoniaceae, or included within the family Circaeasteraceae (Ren et al. 2004; Wang et al. 2009; APG III 2009). In addition, Anemoneae with the remaining two tribes is strongly supported as the monophyletic group in phylogenetic analyses (Jansen et al. 1995; Ro et al. 1997; Wang et al. 2009; Jiang 2017).

Including Anemoclema (Franch.) W. T. Wang, subtribe Anemoninae consists of eight genera: Anemone L., Barneoudia C. Gray, Hepatica Miller, Knowltonia Salisb., Metanemone W. T. Wang, Oreithales Schldl., and Pulsatilla Miller (Wang 1979; Tamura 1995). However, the phylogenetic relationship and taxonomic status of Anemoclema in the subtribe has remained in doubt. Anemoclema glaucifolium (Franch.) W.T.Wang is the only species proposed by Wang (1964) in this genus which was originally described as Anemone glaucifolium (Franchet 1889). The basic chromosome number (i.e. $n=8$ ) of this species is similar to that of Anemone and Clematis (Tamura 1995; Yang 2002; Zhang and Gong 2002). However, recent molecular studies found the close relationships of this species with Clematis L. than to Anemone and suggested to transferred this monotypic genus to Clematidinae from Anemoninae (Zhang et al. 2015; Lehtonen et al. 2016).

The achene anatomy of Anemone has been a long history and proved to be a great value for the infrageneric classification of the genus (Starodubtsev 1991; Tamura 1995; Ziman et al. 2008). Ziman et al. (2008) made an extensive study on the anatomy of 110 species of Anemone and found as many as 25 achenes features with potential diagnostic value. Before that Chaudhary and Trifonova (1988) examined the usefulness of fruit anatomy in the systematic position of 11 Nepalese Anemone. More recently Maciejewska-Rutkowska and Antkowska (2013) demonstrated the significance of achene morphology and anatomy in four Polish Anemone. However, the comparative study of achenes of Anemone species with other genera of subtribe Anemoninae is lacking in the literature. Jung and Heo (2017) listed a few achene anatomical characters of three Anemone, three Hepatica, and two Pulsatilla species in their study but did not discuss the utility of the features within Anemoninae.

We investigated the achene anatomy of 12 species belonging to three genera of subtribe Anemoninae. The primary objectives of this study were (1) to demonstrate the achene morphological and anatomical features of included taxa, and (2) to understand the taxonomic usefulness of achene feature within and between the genera of subtribe Anemoninae.

\section{Methods}


More than 240 achenes from 12 taxa representing three genera (Anemone, Hepatica, and Pulsatila) of tribe Anemoneae originating from the seed bank at the Korea National Arboretum (KH), Pocheon, Korea, were investigated. Names of investigated species with their voucher numbers are given in Table 1.

\section{Light microscopy}

At least three to five achenes of each taxa were considered for microtome sectioning. Microtome sections were prepared using the following procedure. Mature achenes were passed through ethanol series $(50,70$, $80,90,95$ and $100 \%$ ) for dehydration. After complete dehydration, the achenes were infiltered in alcohol/Technovit combinations (3:1, 1:1, 1:3, and 100\% Technovit) and then embedded in Technovit 7100 resin. The embedded materials were cut into serial sections of 4-6 $\mu \mathrm{m}$ thickness using a Leica RM2255 rotary microtome (Leica Microsystems $\mathrm{GmbH}$, Germany) with disposable blades, stuck onto a slide glass, and dried using an electric slide warmer for $12 \mathrm{~h}$. Dried slides were stained with $0.1 \%$ Toluidine blue ' $\mathrm{O}$ ' for $60-90 \mathrm{~s}$, rinsed with water and again dried in slide warmer for more than $6 \mathrm{~h}$ to remove water. The stained slides were then mounted with Entellan (Merck Co., Germany) and permanent slides were prepared. The permanent slides were examined under an AXIO Imager A1 light microscope (Carl Zeiss, Germany). Photomicrographs were taken with an AxioCam MRc5 attached camera system, and pericarp measurements were made using AxioVision software for Windows (release 4.7, 2008). Multiple image alignment was done using Photoshop CS for Windows 2010. None of the image-alteration facilities of Photoshop were used to change the original images captured by the camera.

\section{Morphometry and data analysis}

A total of approximately 240 achenes were used for morphometric measurement. Digital images of whole achenes were taken with a Leica DFC420 C multifocal camera attached to a Leica MZ16 FA microscope (Leica Microsystems). The length and width 20 seeds from each taxon were measured by Leica LAS V3.8 software for Windows. The biometric data were analyzed statistically. For each seed variables, one-factor analysis of variance (ANOVA) was used to examine differences in means among the included species. Pearson's correlation coefficients were used to estimate the relationship among the achene length, width, pericarp and endocarp thickness, diameter cross section, and their relative ratios. All of the statistical analyses were carried out using the SPSS statistical program (IBM SPSS Statistics for Windows Version 20.0., IBM Corp., Armonk, USA). Cluster analysis based on the paired group (UPGMA) of six quantitative (excluding ratios) and 11 qualitative achene characters was also performed to verify achene features allowed the grouping of the species by using the statistical program PAST ver. 3.25 (Hammer et al. 2001). Character states and their coding are given in supplementary file S1.

\section{Results}

Selected stereomicroscopic image of single achene and light microscopic images of pericarp structure was given in Figures 1-4. A comprehensive description of the morphological features of achenes and anatomical features of pericarp was presented below. 


\section{Anemone L.}

Altogether, five species of Anemone were investigated in this study. The achenes are elliptical or obovoid flattened with brown to pale yellow in color (Fig. 1A-F; Table 2). The largest achenes were measured for A. narcissiflora $(7.75 \pm 0.82 \times 5.58 \pm 0.66 \mathrm{~mm})$ followed by $A$. narcissiflora subsp. crinita $(7.24 \pm 0.51 \times$ $4.49 \pm 0.63 \mathrm{~mm})$ whereas the smallest achenes were measured for $A$. raddenea $(2.26 \pm 0.18 \times$ $1.18 \pm 0.11 \mathrm{~mm})$ followed by $A$. reflexa $(2.42 \pm 0.24 \times 0.84 \pm 0.09 \mathrm{~mm})($ Table 3$)$. Out of five, three species $(A$. koraiensis, $A$. raddeana, and $A$. reflexa) have hairs on the achene surface and narrow wings but the remaining two ( $A$. narcissiflora subsp. crinita and $A$. narcissiflora) have glabrous achene surface and wide wings. All the species have a hooked persistent style.

The elliptical achenes are oval outlined in the cross-section whereas obovoid achenes are elliptical. Endosperm diameter is corresponding with the length and width of achenes. In cross-section, the thickest pericarp has found in $A$. koraiensis $(206.78 \pm 17.47 \mu \mathrm{m})$ followed by $A$. narcissiflora $(149.27 \pm 15.3 \mu \mathrm{m})$ and the thinnest pericarp has measured in $A$. narcissiflora subsp. crinita $(43.53 \pm 6.03 \mu \mathrm{m})$ followed by $A$. raddeana $(56.65 \pm 13.89 \mu \mathrm{m})$. Interestingly, $A$. koraiensis which has thickest pericarp bear exceptionally thinnest endocarp $(9.79 \pm 1.99 \mu \mathrm{m})$. The thickest endocarp is of $A$. narcissiflora $(29.84 \pm 4.62 \mu \mathrm{m})$ followed by $A$. raddeana $(25.49 \pm 5.25 \mu \mathrm{m})$. The exocarp in Anemone species is highly cutinized and cells are usually crushed except $A$. koraiensis and $A$. reflexa which have rectangular or elongated exotestal cells (Fig. 2A-L). The exocarp layer is followed by the well-represented parenchymatous mesocarp in $A$. koraiensis, $A$. reflexa, and $A$. narcissiflora (Fig. 2B, $\mathrm{F}, \mathrm{L}$ ) but this region is represented by few layers of crushed cells in $A$. raddeana and $A$. narcissiflora subsp. crinita (Fig. 2D, H, J). All the observed species have lignified, either palisade like or sclereid, endocarp regardless of variation in their thickness (Fig. 2B, $D, F, H, J, L)$. In all species, the seed coat is feebly established, which is either represented by a couple of parenchyma layers or contains degenerating cells.

\section{Hepatica Mill.}

Three species of Hepatica are included in this study. Achene morphology including shape, size, color, and anatomy of pericarp, endocarp, and seed coat display relatively similar qualitative features and quantitative measurements. The achenes are stalked, obovoid, pale yellow to brown or black in color, and pubescent $(H$. asiatica, $H$. insularis) or glabrous $(H$. maxima) in surface texture (Fig. 3; Table 2$)$. $H$. maxima has comparatively larger achenes $(3.35 \pm 0.32 \times 1.9 \pm 0.29 \mathrm{~mm})$ than other two species $H$. asiatica $(2.11 \pm 0.23 \times 1.32 \pm 0.15 \mathrm{~mm})$ and $H$. insularis $(2.43 \pm 0.19 \times 1.41 \pm 0.11 \mathrm{~mm})$. The lateral wings are small in Hepatica and persistent style develops into a long slender beak.

In the cross-section, Hepatica achenes are circular in outline (Figs. 4A, C, E). The endosperm diameter is equivalent to the size of achenes, larger the achenes bigger the endosperm diameter (Table 3). Likewise, the pericarp is thicker in $H$. maxima $(274.38 \pm 27.83 \mu \mathrm{m})$ than $H$. asiatica $(99.04 \pm 8.35 \mu \mathrm{m})$ and $H$. insularis $(126.85 \pm 13.57 \mu \mathrm{m})$ but endocarp is relatively comparable in all species, as a result, the ratio of pericarp and endocarp thickness is relatively higher in H. maxima (Table 3). The exocarp is single-layered, cutinized and its cells are tangentially elongated $(H$. asiatica, $H$. insularis) or rectangular $(H$. maxima) in 
shape (Fig. 4B, D, F). The mesocarp is mostly crushed in $H$. asiatica, represented by 2-3 layers of parenchyma cells in $H$. insularis, and 3-5 layers of elongated parenchyma cells with wavy cell walls in $H$. maxima. The endocarp is multilayered and cells are highly lignified whereas seed coat in all species is represented by 2-3 layers of degenerating cells (Fig. 4B, D, F).

\section{Pulsatilla Mill.}

Four species of Pulsatilla are observed. The result of this study indicates that Pulsatilla species exhibit very similar achene morphological and anatomical structures. The achenes are much longer than wider, elliptical in shape, brown to black in color, and profoundly hirsute with white and shiny long hair (Fig. 3; Table 2). The largest achenes are of $P$. tongkangensis $(4.07 \pm 0.24 \times 1.17 \pm 0.51 \mathrm{~mm})$ and the smallest achenes are of $P$. dahurica $(2.7 \pm 0.3 \times 0.87 \pm 0.08 \mathrm{~mm})$. The lateral wings are narrow and the persistent style forms long slender beak.

In the cross-section, the achenes are circular in outline (Fig. 4G, I, K). The endosperm diameter in the cross-section is comparable to the width of achenes as in Anemone and Hepatica species (Table 3). Corresponding with the achene size, the pericarp, and the endocarp is thickest in $P$. tongkangensis $(58.63 \pm 8.199 \mu \mathrm{m}$ and $32.84 \pm 3.35 \mu \mathrm{m}$, respectively), however, the thinnest pericarp $(32.11 \pm 5.78 \mu \mathrm{m})$ and endocarp $(18.24 \pm 3.41 \mu \mathrm{m})$ is measured for $P$. cernum. The exocarp is mostly crushed or rarely present as the fragmented cells in all four species (Fig. $4 \mathrm{H}, \mathrm{J}, \mathrm{L}$ ). The mesocarp is represented by undistinguishable layers of degenerated cells whereas the endotesta comprised of a thick single layer of highly lignified sclereid cells. The seed coat is also represented by degenerated cells except in $P$. tongkangensis which has 2-3 layers of elongated cells with thickened walls (Fig. 4L).

\section{Statistical analyses}

One-factor ANOVA was performed on nine quantitative achene traits and the differences between species were found to be highly significant (Table 3). Pearson's correlation coefficient also indicated a significant correlation between different achene traits. The differences in thickness of pericarp and endocarp are presented in boxplots (Fig. 5A, B). The relationships among the species through six quantitative and 11 qualitative features were revealed using cluster analysis (Fig. 6). The cluster analysis based on the paired group (UPGMA) algorithm using Gower similarity index obtained three clades. Anemone narcicciflora complex represented the basal clade of the UPGMA tree whereas three Hepatica species remained at the top of the tree. The third clade represented by two subclades in which A. reflexa and A. koraiensis separated first and $A$. reddeana grouped with four Pulsatilla species.

\section{Discussion}

Molecular phylogenetic studies suggested a wider perception of Anemone incorporating Hepatica, Pulsatilla, and Knowltonia (Hoot et al. 1994; Schuettpelz et al. 2002; Meyer et al. 2010). The group of these taxa also share some similar morphological characters like rosette basal leaves with a variety of perennating structures, inflorescence with involucre leaves on the peduncle, petaloid sepals, and similar 
achene features. However, there have been differences in few morphological features like close proximity to the flower and stalked achenes of Hepatica, elongated plumose style in Pulsatilla, and berry-like fruits in Knowltonia with Anemone as well (Hoot et al. 1994). We compared the achene morphology and anatomy of 12 taxa belonging to three genera excluding Knowltonia from Anemone complex.

Comparing the gross morphology, achenes of studied taxa exhibited variations in the shape, size, color, surface, wings, and remnant of style. ANOVA of quantitative variables revealed the significant differences in length and width of achene among the taxa $(P<0.001)$ (Table 3$)$ and Pearson's correlation coefficients showed the positive relationship between length and width $(r=0.934, P<0.01)$. Among the qualitative features, surface, wings, and style are highly variable within and between the genera. In previous studies achene characters like size, shape, and style have been proved useful to distinguish species in the genus Anemone (Saoud et al. 2007; Ziman et al. 2008, 2011; Maciejewska-Rutkowska and Antkowska, 2013) and the result of this study evidently demonstrates this fact. The five species of Anemone clearly divided into two groups based on the shape, surface, and wings. Anemone narcissiflora, and A. narcissiflora subsp. crinita which are belonging to sub-genus Omalocarpus had obovoid and flattened achenes with glabrous surface and wide wings whereas $A$. koraiensis, $A$. raddeana, and $A$. reflexa belonging to subgenus Anemonanthea had elliptical achenes with pubescent surface and narrow wings. On the other hand, the presence of hooked style in all species of Anemone differentiates this genus from Hepatica and Pulsatilla species which had slender style.

A similar result was obtained from achene anatomy as well. Achenes of Hepatica and Pulsatilla are circular in outline whereas achenes of Anemone are oval to elliptical in cross-section. The quantitative variables indicated that the pericarp and endocarp thickness and achene diameter in the cross-section in both planes varies significantly among the species $(P<0.001)$. The pericarp thickness is positively correlated with endocarp thickness $(r=0.498 ; P<0.01)$ and diameter in cross-section in both planes $(r=$ $0.487 ; P<0.01$ and $r=0.8 ; P<0.01)$ whereas endocarp thickness is negatively related with achene length $(r=-0.318 ; P<0.01)$ and width $(r=-0.167 ; P<0.05)$. Among the qualitative features, the nature of exocarp, mesocarp, and endocarp are important as seed coat is poorly represented in all taxa.

In cross-section, Anemone achenes are oval or elliptical with narrow to wide extensions in which the vascular bundles are present. The achene anatomy of Anemone has been extensively studied in the past. Recently, Ziman et al. (2008) and Maciejewska-Rutkowska and Antkowska (2013) emphasizes the taxonomic value of pericarp in this genus. Before that Chaudhary and Trifonova (1988) distinguished epicarp, mesocarp, and endocarp in 11 species of Anemone and highlighted the significance of a number of cell layers and cell form in individual pericarp layers. Even within a very limited sampling (five species), we found a similar result in this study. Exocarp is cutinized with rectangular to elongated cells in Anemone koraiensis and $A$. reflexa but the cells are crushed in other three species although few fragmented exotestal cells are found in A. narcissiflora. An almost a similar trend observed for mesocarp except for a number of cell layers. However, the most significant feature in Anemone seems to be the nature of endocarp which clearly separated the two subgenera in our sampling. The endocarp is exclusively single-layered and the cells are highly lignified and palisade like in $A$. raddeana and $A$. reflexa 
which are belong to subgenus Anemonanthea. However, cells are highly lignified and sclereid and singlelayered in Anemone narcissiflora, and two to three-layered in A. narcissiflora subsp. crinita which are belonging to subgenus Omalocarpus. The endocarp is a thin layer of thick-walled rectangular cells in $A$. koraiensis. Morphologically, A. koraiensis closely related to $A$. reflexa and both species share similar vegetative forms, a white solitary flower with five sepals, and a pubescent achene surface (Sung 2017). The results of this also agree with Sung (2017) as these two species formed a distinct subclade on the Pulsatilla-Anemone clade in the UPGMA tree.

In Hepatica the exotesta is well represented with tangentially elongated cells as in $\mathrm{H}$. asiatica and $\mathrm{H}$. insularis or wide rectangular cells as in H. maxima. Along with the exocarp, H. maxima also revealed 3-5 cell layers thick meso- and maximum of four cells layered endotesta instead of 1-2 layered meso- and maximum of three-layered endotesta in $\mathrm{H}$. asiatica and $\mathrm{H}$. insularis. The result of this study agrees with Nakai (1952) who divided these three Korean species into two groups, $H$. asiatica and $H$. insularis with annual leaves and $H$. maxima with biennial leaves and Pfosser et al. (2011) who found a genetically close relation between $H$. asiatica and $H$. insularis. The qualitative achene features of four Pulsatilla species included in this study are astonishingly similar in every detail. This is not surprising though because in the recent taxonomic treatment of the genus by Grey-Wilson (2014), all four species investigated in this study are belonged to the same section Semicampanaria of subgenus Pulsatilla.

\section{Declarations}

\section{Ethics approval and consent to participate}

Not applicable.

\section{Consent for publication}

Not applicable.

\section{Availability of data and material}

Not applicable

\section{Competing interests}

The authors declare no conflict of interests.

\section{Funding}

Not applicable

\section{Supplemental information}

Supplemental information for this article can be found online version. 


\section{Author contributions}

Conceptualization; Balkrishna Ghimire and Mi Jin Jeong; Experiments; Balkrishna Ghimire; Statistical analysis; Dabin Yum and, Dong Chan Son; Manuscript writing; Balkrishna Ghimire; Review and editing; Dong Chan Son and Jae Hyun Kim; Funding Acquisition; Jae Hyun Kim and Mi Jin Jeong.

\section{Acknowledgements}

This study was financially supported by the project 'Ex-situ Conservation of Forest Plant Seeds in Korea (KNA1-2-29).

\section{References}

APG III (2009) An update of the Angiosperm Phylogeny Group classification for the orders and families of flowering plants: APG III. Bot J Linnean Soc 161:105-121.

Chaudhary RP, Trifonova VI (1988) Morphology of fruit and comparative anatomy of pericarp and seed coat in the Nepal species of the genus Anemone (Ranunculaceae). Bot Z 73(6):803-817.

Emadzade K, Lehnebach C, Lockhart P, Hörandl E (2010) A molecular phylogeny, morphology and classification of genera of Ranunculeae (Ranunculaceae). Taxon 59: 809-828.

Franchet A (1889.) Plantae delavayae, Vol 1. Paul Klineksieck, Paris, pp 6-7

Grey-Wilson C (2014) Pasque-flowers. The genus Pulsatilla. Kenning hall: The Charlotte Louise Press.

Hammer $\varnothing$, Harper DAT, Ryan PD (2001) PAST: Paleontological Statistics Software Package for Education and Data Analysis. Palaeontologia Electronica 4(1): 9pp.

Heywood VH, Brummitt RK, Culham A, Seberg O (2007) Plant families of the world. Richmond Hill, Ontario, Canada: Firefly Books.

Hoot SB, Reznicek AA, Palmer JD (1994) Phylogenetic relationships in Anemone (Ranunculaceae) based on morphology and chloroplast DNA. Syst Bot 19: 169-200.

Hutchinson J (1923) Contributions towards a phylogenetic classification of flowering plants I. Bull Misc Inform Kew 2, 65-89.

Janchen E (1949) Die systematische Gliederung der Ranunculaceen und Berberidaceen. Denkschr Österr Akad Wiss Math -Naturwiss KI 108: 1-82.

Jensen U, Hoot SB, Johansson JT, Kosuge K (1995) Systematics and phylogeny of the Ranunculaceae - a revised family concept on the basis of molecular data. PI Syst Evol (Suppl.) 9: 273-280. 
Jiang N, Zhou Z, Yang JB, Zhang SD, Guan KY, Tan YH, Yu WB (2017) Phylogenetic reassessment of tribe Anemoneae (Ranunculaceae): non-monophyly of Anemone s.l. revealed by plastid datasets. PLoS One 12, e0174792. doi: 10.1371/ journal. pone.0174792

Johansson JT, Jansen RK (1993) Chloroplast DNA variation and phylogeny of the Ranunculaceae. Plant Syst Evol 187: 29-49.

Jung WC, Heo K (2017) Fruit and seed morphology of Korean Ranunculaceae. Korean J PI Taxon 47: 137-153.

Lehtonen S, Christenhusz MJ, Falck D (2016) Sensitive phylogenetics of Clematis and its position in Ranunculaceae. Bot J Linn Soc 182: 825-867. doi: 10.1111/boj.12477

Maciejewska-Rutkowska I, Antkowska W (2013) Taxonomic utility of achene morphology and anatomy in Anemone L. (Ranunculaceae) species. Acta Biol Carcov Bot 55: 29-36.

Meyer KM, Hoot SB, Arroyo MTK (2010) Phylogenetic affinities of south American Anemone (Ranunculaceae), including the endemic segregate genera, Barneoudia and Oreithales. Int J Plant Sci 171: 323-331. doi: 10.1086/650153.

Nakai T (1952) A synoptical sketch of Korean flora. Bull Nat Sci Mus 1-27

Pfosser M, Sun B-Y, Stuessy TF, Jang C-G, Guo Y-P, Taejin K, Hwan KC, Kato H, Sugawara T (2011) Phylogeny of Hepatica (Ranunculaceae) and origin of Hepatica maxima Nakai endemic to Ullung Island, Korea. STAPFIA 95:16-27.

Ren Y, Li ZJ, Chang HI, Lei YJ, Lu AM (2004) Floral development of Kingdonia (Ranunculaceae s. I., Ranunculales). Plant Syst Evol 247:145-53.

Saoud SN, Knio K, Jury S (2007) Phenetic analysis of Anemone coronaria (Ranunculaceae) and related species. Bot J Linn Soc 153: 417-438.

Schuettpelz EJ, Hoot SB, Samuel R, Ehrendorfer F (2002) Multiple origins of Southern Hemisphere Anemone (Ranunculaceae) based on plastid and nuclear sequences. Plant Syst Evol 231: 143-151.

Simpson MG (2006) Plant systematics. Elsevier, Amsterdam.

Soltis DE, Soltis PS, Endress PK, Chase MW (2005) Phylogeny and evolution of angiosperms. Sinauer Associates, Sunderland, Massachusetts.

Starodubtsev VN (1991) Anemone: Systematics and evolution. Leningard: Akad, Nauk SSSR

Tamura M (1995) Angiospermae: Ordnung Ranunculales. Fam. Ranunculaceae In: Hiepko P [ed.], Die Natürlichen Pflanzenfamilien. Vol. 17a(4), 324-349. Duncker \& Humblot, Berlin. 
Sung HY (2017) Anemone L. Flora of Korea: Volume 2a, Magnoliidae, 60-64p.

The Plant List (2013) Version 1.1. Published on the Internet; http://www.theplantlist.org/ (accessed 1st January).

Wang WT (1964) Duo genera nova Rannuculacearum Sinensium. Acta Phytotaxon Sin 9: 103-7.

Wang WT (1979) Tribe Anemoneae DC. In: Anonymous (ed) Flora Reipublicae Popularis Sinica, Vol 28. Science Press, Beijing, pp 1-141

Wang W, Lu A-M, Ren Y, Endress ME, Chen Z-D (2009) Phylogeny and classification of Ranunculales: Evidence from four molecular loci and morphological data. Perspect Plant Ecol Evol Syst 11:81-110.

Yang QE (2002) Cytology of ten species in Anemone, one in Amemoclema and six Clematis (Trib. Anemoneae, Ranunculaceae) from China. Acta Phytotaxa Sin 40: 396-405.

Ziman SN, Bulakh EV, Kadota Y, Keener CS (2008) Modern view on the taxonomy of the genus Anemone L. sensu stricto (Ranunculaceae). J Jap Bot 83: 127-155.

Zhang GL, Gong X (2002) The karyotype analysis of Anemoclema glaucifolium and Heteroplexis microcephala bot endemic to China. Acta Bot Yunnan 24: 765-768.

Zhang Y, Kong HH, Yang QE (2015) Phylogenetic relationships and taxonomic status of the monotypic Chinese genus Anemoclema (Ranunculaceae). Plant Syst Evol 301:335-44.

\section{Tables}

Table 1 Name of taxa with voucher number and collection information.

\begin{tabular}{ll}
\hline Taxon & Voucher No. \\
\hline Anemone koraiensis Nakai & L10335 \\
Anemone raddeana Regel & L2030 \\
\hline Anemone reflexa Steph. Ex. Willd & L8045 \\
\hline Anemone narcissiflora L. & L14911 \\
\hline Anemone narcissiflora subsp. crinita (Juz.) Kitag & L10766 \\
\hline Hepatica asiatica Nakai & L3363 \\
\hline Hepatica insularis Nakai & L9859 \\
\hline Hepatica maxima (Nakai) Nakai & $2015 \mathrm{UL001}$ \\
\hline Pulsatilla dahurica (Fisch. Ex DC.) Spreng & L12332 \\
\hline Pulsatilla cernua (Thunb.) Bercht. ex J. Presl & L13107 \\
\hline Pulsatilla koreana Nakai & L12512 \\
\hline Pulsatilla tongkangensis Y.N.Lee \& T.C.Lee & L12843 \\
\hline
\end{tabular}


Table 2 Morphological and anatomical features of achene of Anemoninae.

Page 12/21 


\begin{tabular}{lllllll}
\hline Taxon & Shape & Color Surface Wings Style & Shape in Exocarp \\
CS
\end{tabular}

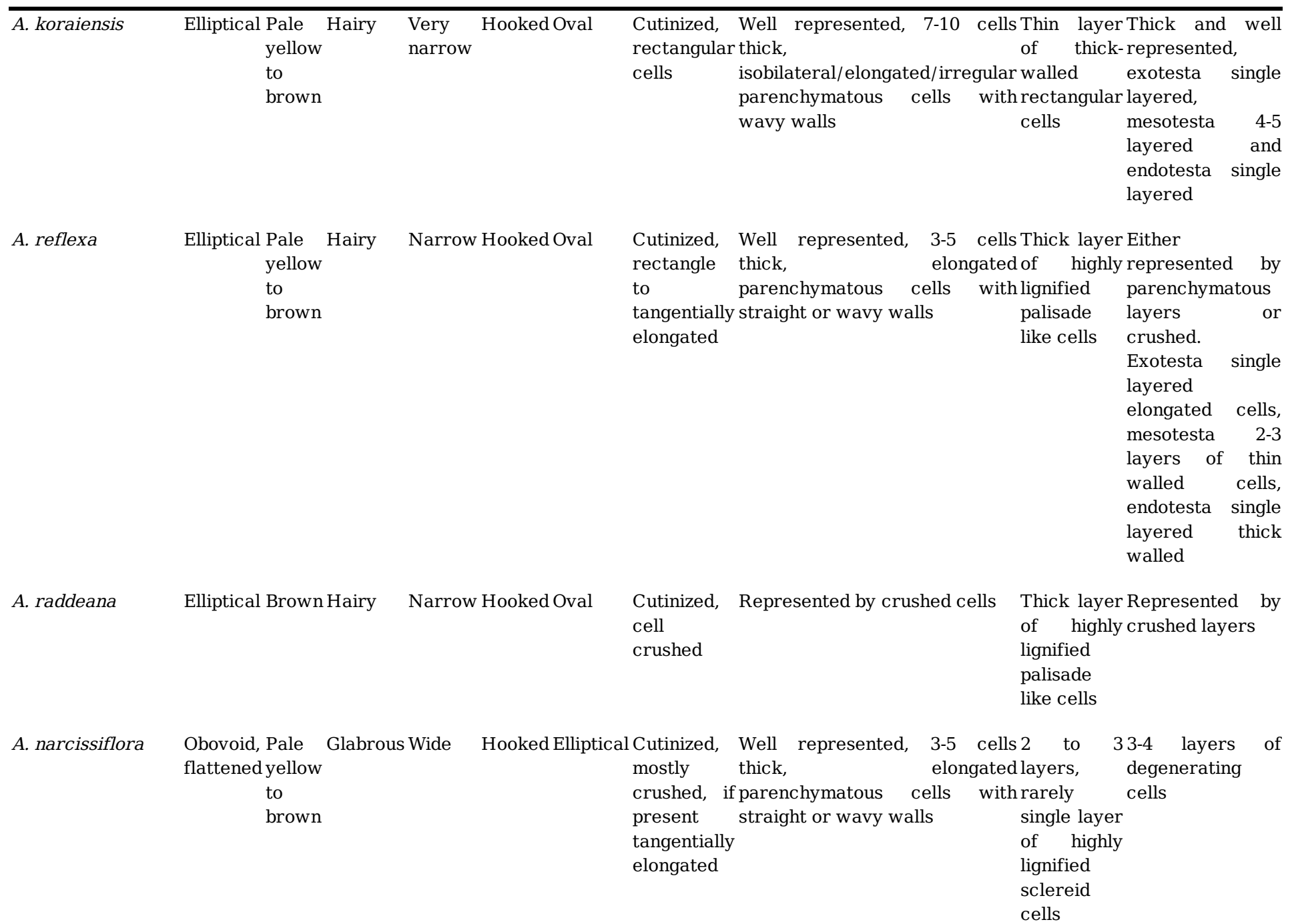

A. Obovoid, brown Glabrous Wide Hooked Elliptical Cutinized, Represented by crushed cells Thick layer Represented by narcissiflora subsp. flattened cell crinita crushed of highly crushed layers lignified sclereid cells

\begin{tabular}{|c|c|c|c|c|}
\hline H. asiatica & Obovoid & $\begin{array}{l}\text { Pale Hairy } \\
\text { yellow } \\
\text { to } \\
\text { brown }\end{array}$ & $\begin{array}{c}\text { Narrow Slender Circular Cutinized, } 1-2 \text { layers of } \\
\text { tangentially parenchyma cells. } \\
\text { elongated }\end{array}$ & $\begin{array}{l}\text { elongated } 2 \text { to } 32-3 \text { layers } \\
\text { layers, degenerating } \\
\text { rarely cells } \\
\text { single layer } \\
\text { of highly } \\
\text { lignified } \\
\text { palisade } \\
\text { cells }\end{array}$ \\
\hline
\end{tabular}

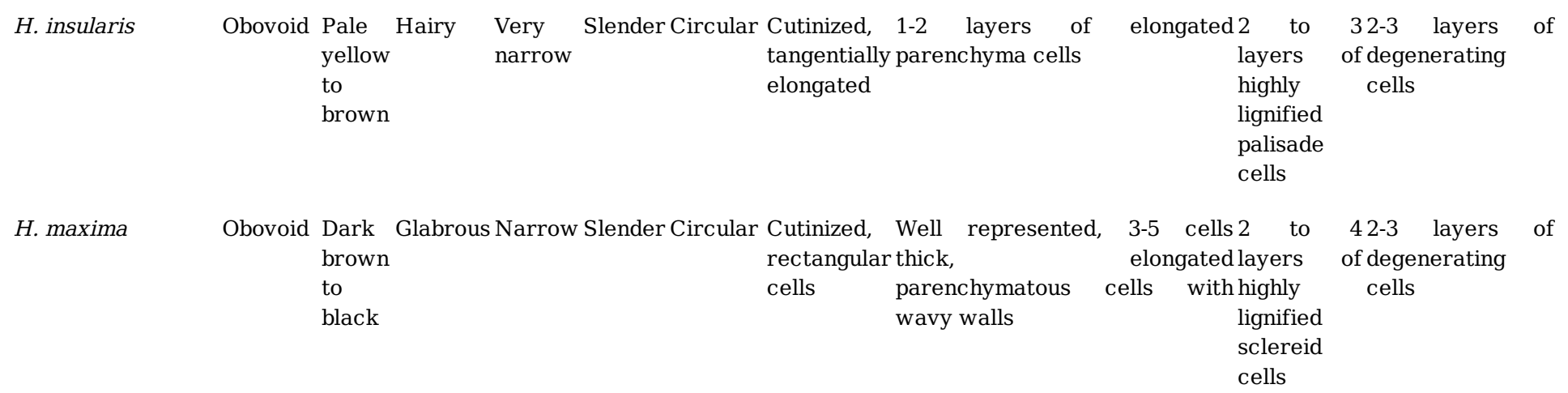


P. dahurica

Elliptical Brown Hairy

Narrow Slender Circular Crushed

P. cernua

Narrow Brown Hairy elliptical to

black

Narrow Slender Circular Crushed

\section{$\mathrm{R}$}

ented by crushed cells

P. koreana

Narrow Brown Hairy elliptical to

black

Narrow Slender Circular Crushed

$\mathrm{R}$

Represented by crushed cells


Table 4 Pearson's correlation coefficients between different seed features in Anemoninae species. L/W = length and width ratio, $\mathrm{P} / \mathrm{E}=$ pericarp and endocarp ratio, CSD1 = diameter parallel to cotyledon, CSD2 = diameter perpendicular to cotyledon, D1/D2 = CSD1 and CSD2 ratio.

\begin{tabular}{|c|c|c|c|c|c|c|c|c|c|}
\hline & Length & Width & $\mathrm{L} / \mathrm{W}$ & Pericarp & Endocarp & $\mathrm{P} / \mathrm{E}$ & CSD1 & CSD2 & $\mathrm{D} 1 / \mathrm{D} 2$ \\
\hline \multicolumn{10}{|l|}{ Length } \\
\hline Width & $.934^{* *}$ & & & & & & & & \\
\hline $\mathrm{L} / \mathrm{W}$ & $-.334^{* *}$ & $-.605^{* *}$ & & & & & & & \\
\hline Pericarp & -.095 & .062 & $-.411^{* *}$ & & & & & & \\
\hline Endocarp & $-.318^{* *}$ & $-.167^{*}$ & $-.308^{* *}$ & $.498^{* *}$ & & & & & \\
\hline $\mathrm{P} / \mathrm{E}$ & -.007 & .042 & $-.185^{* *}$ & $.510^{* *}$ & $-.317^{* *}$ & & & & \\
\hline CSD1 & $.674^{* *}$ & $.838^{* *}$ & $-.820^{* *}$ & $.487^{* *}$ & .229 & .098 & & & \\
\hline CSD2 & .050 & $.259^{*}$ & $-.699^{* *}$ & $.800^{* *}$ & $.765^{* *}$ & .077 & $.662^{* *}$ & & \\
\hline $\mathrm{D} 1 / \mathrm{D} 2$ & $.852^{* *}$ & $.875^{* *}$ & $-.492^{* *}$ & -.025 & $-.333^{* *}$ & .063 & $.766^{* *}$ & .042 & \\
\hline
\end{tabular}

**Sig. at 0.01 level *Sig. at 0.05 level.

\section{Figures}
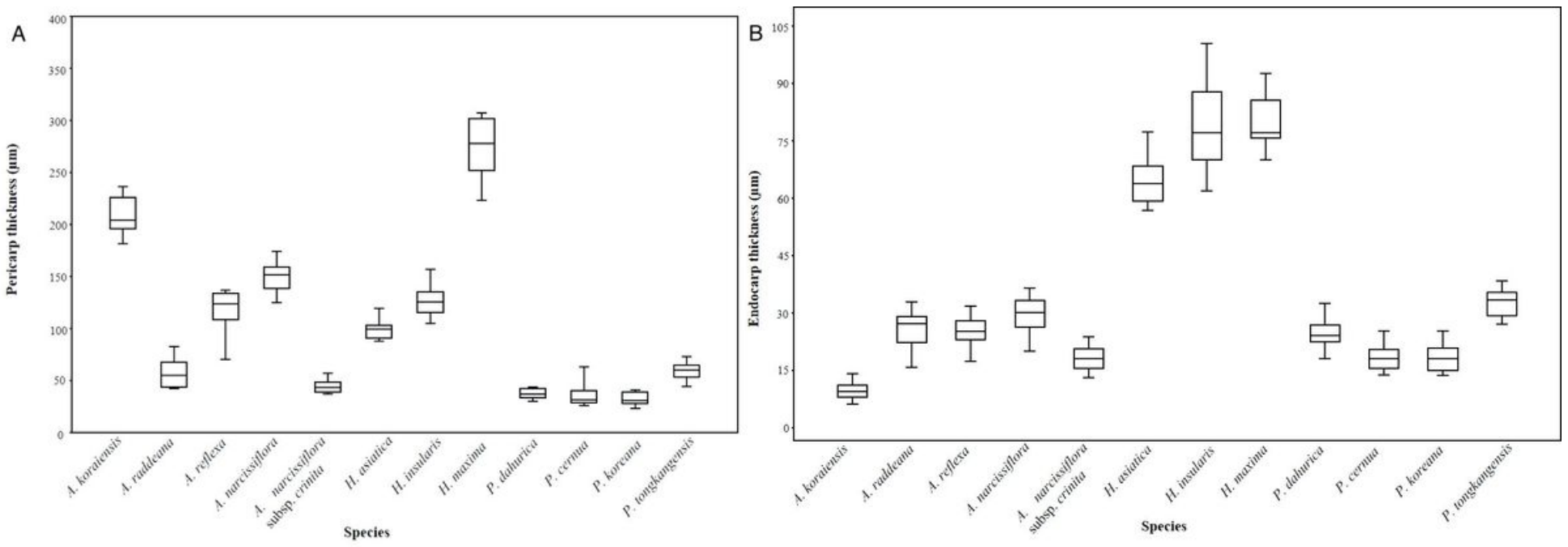

Figure 1

Normal boxplot showing pericarp and endocarp thickness of achene. A. Pericarp. B. Endocarp. 

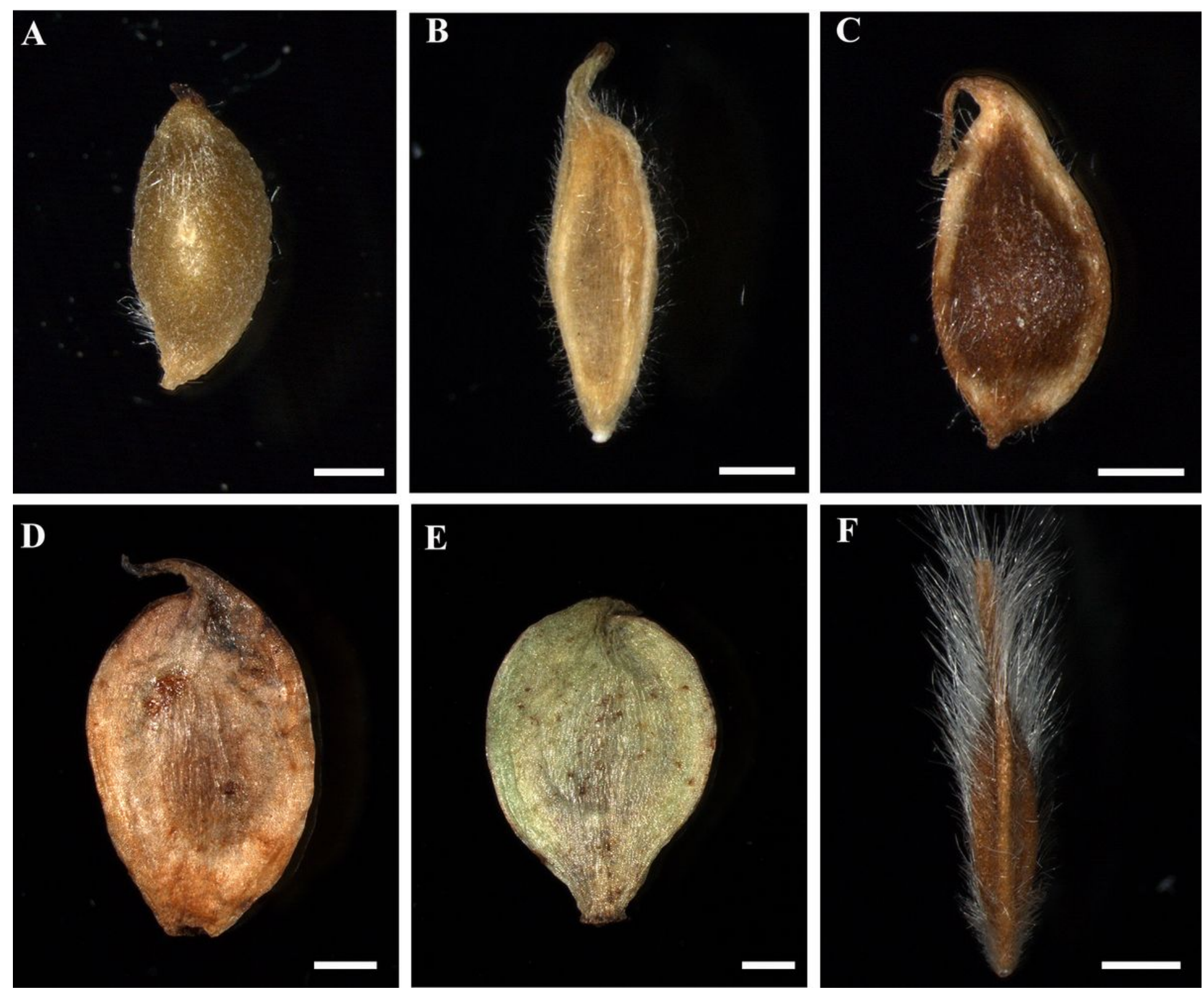

\section{Figure 2}

Achenes of Anemone under stereomicroscope. A. A. koraiensis. B. A. reflexa. C. A. raddeana. D A. narcissiflora subsp. crinita. E. A. narcissiflora. F. P. tongkangensis. Scale bars: A, B, C = 0.5mm; D, E, F = 1 $\mathrm{mm}$. 

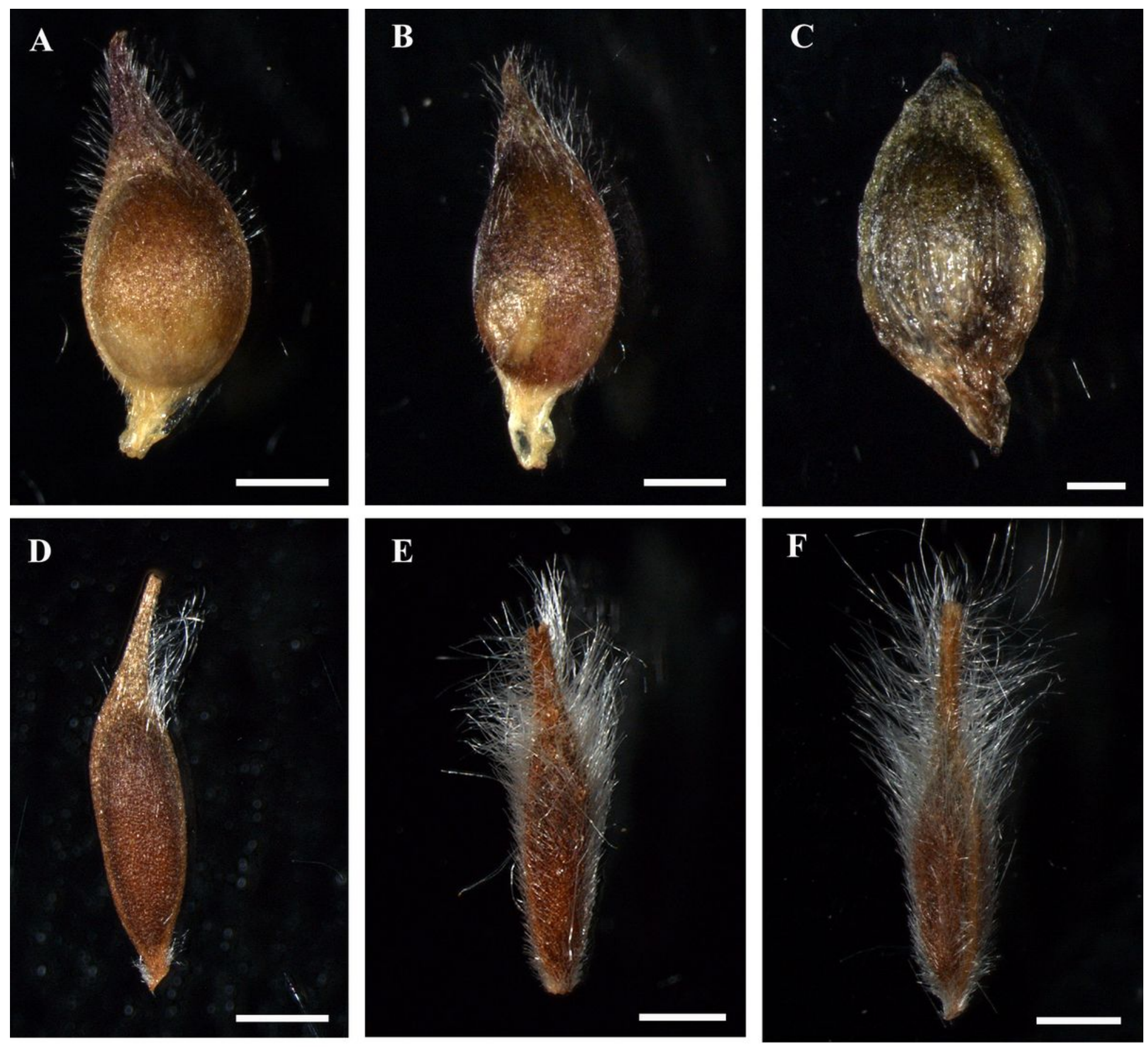

\section{Figure 3}

Achenes of Hepatica and Pulsatilla under stereomicroscope A. H. asiatica. B. H. insularis. C. H. maxima. D. P. dahurica. E. P cernua. F. P koreana. Scale bars: A-F $=1 \mathrm{~mm}$. 
A
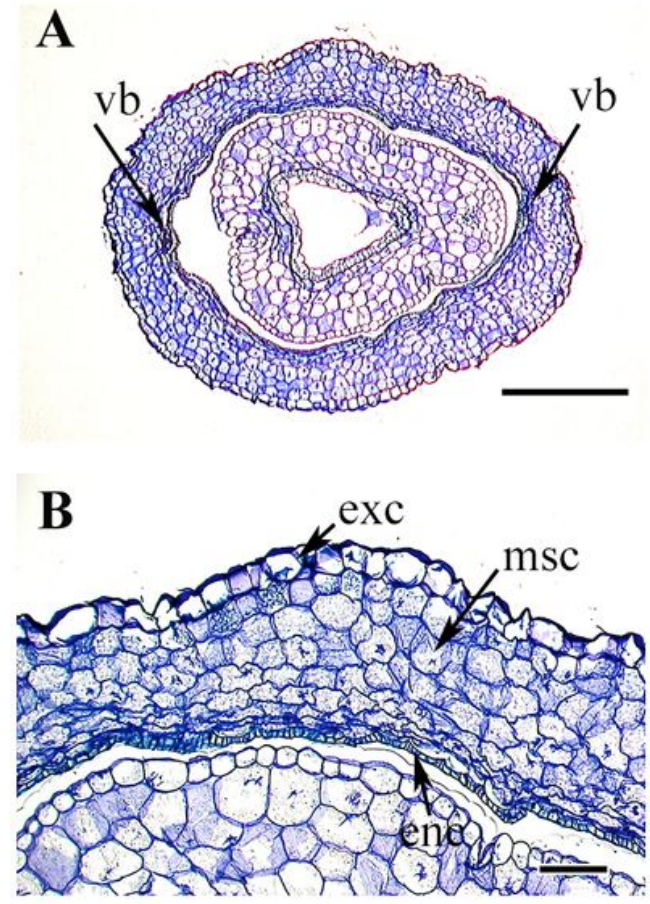

G
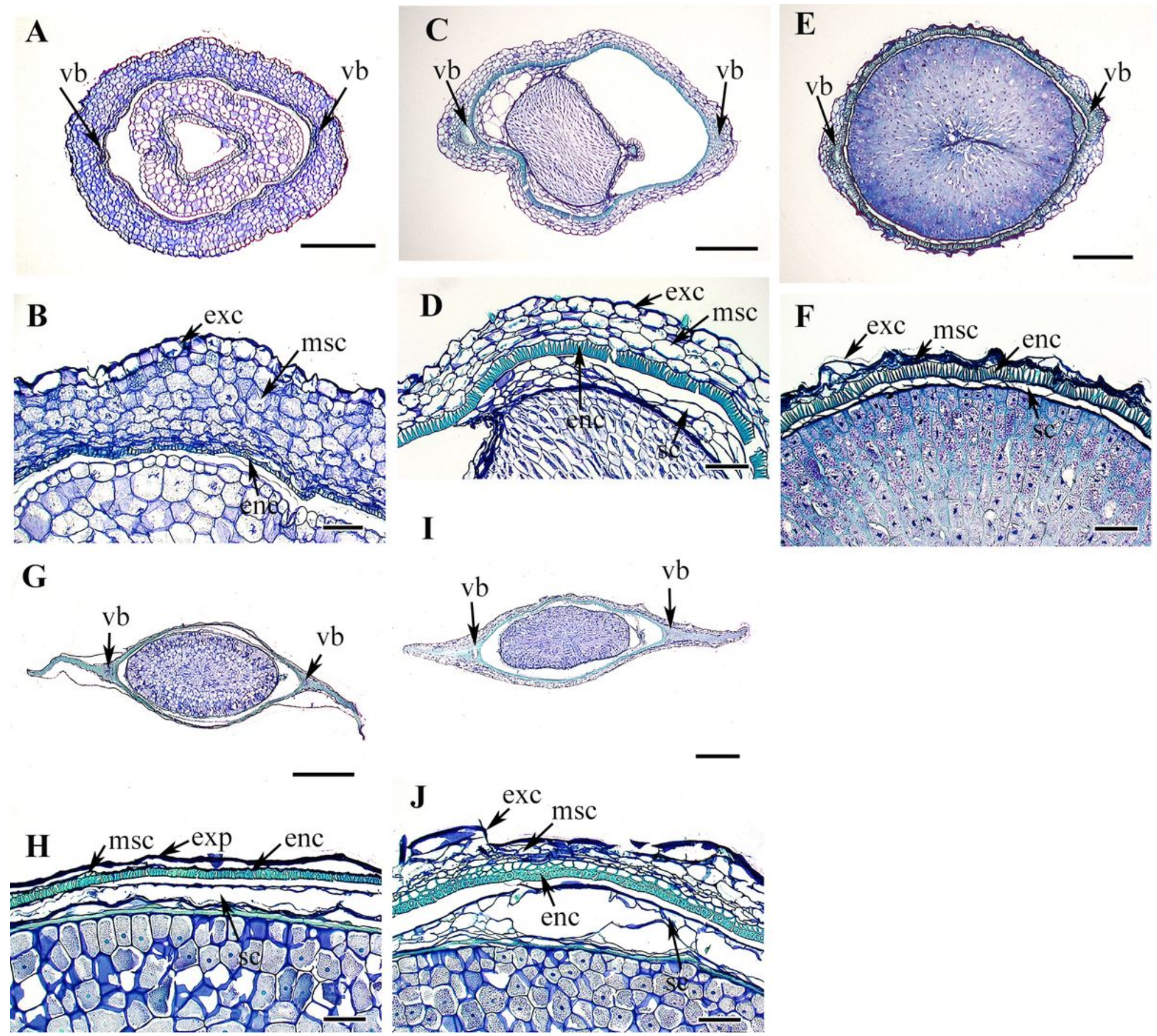

Figure 4

Cross section of Anemone achenes. A, B. A. koraiensis. C, D. A. reflexa. E, F. A. raddeana. G, H. L. A. narcissiflora subsp. crinita. I, J. A. narcissiflora. Scale bars: $A, C, E=0.5 \mathrm{~mm} ; B, D, F, H, J=0.1 \mathrm{~mm} ; \mathrm{G}, \mathrm{I}=$ $1 \mathrm{~mm}$. Abbreviations: en, endocarp; end, endosperm; ex, exocapr; ms, mesocarp; sc, seed coat; vb, vascular bundle. 

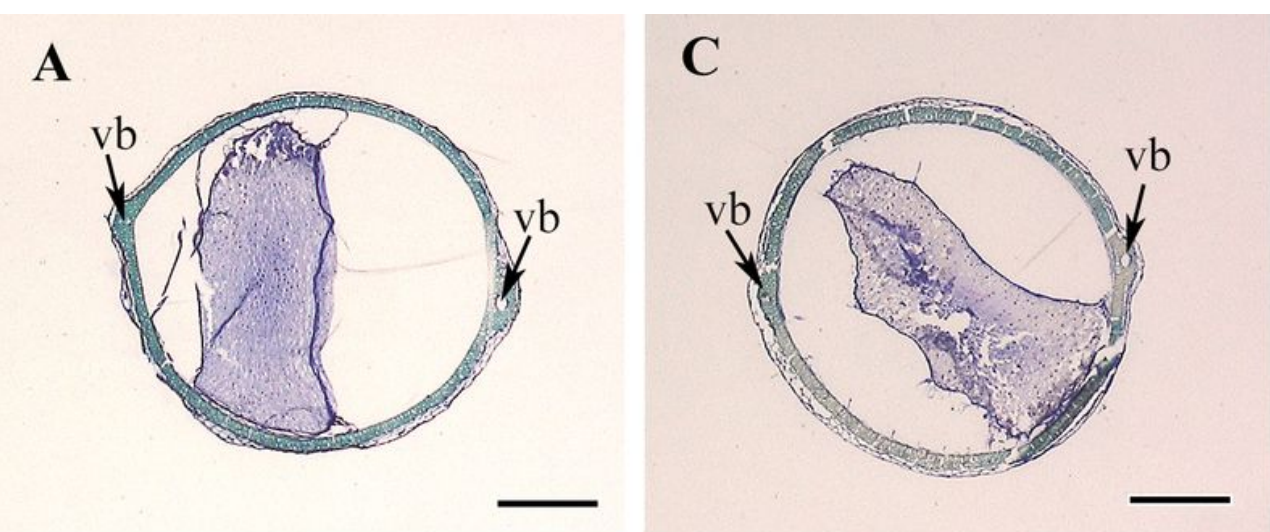

$\mathbf{E}$
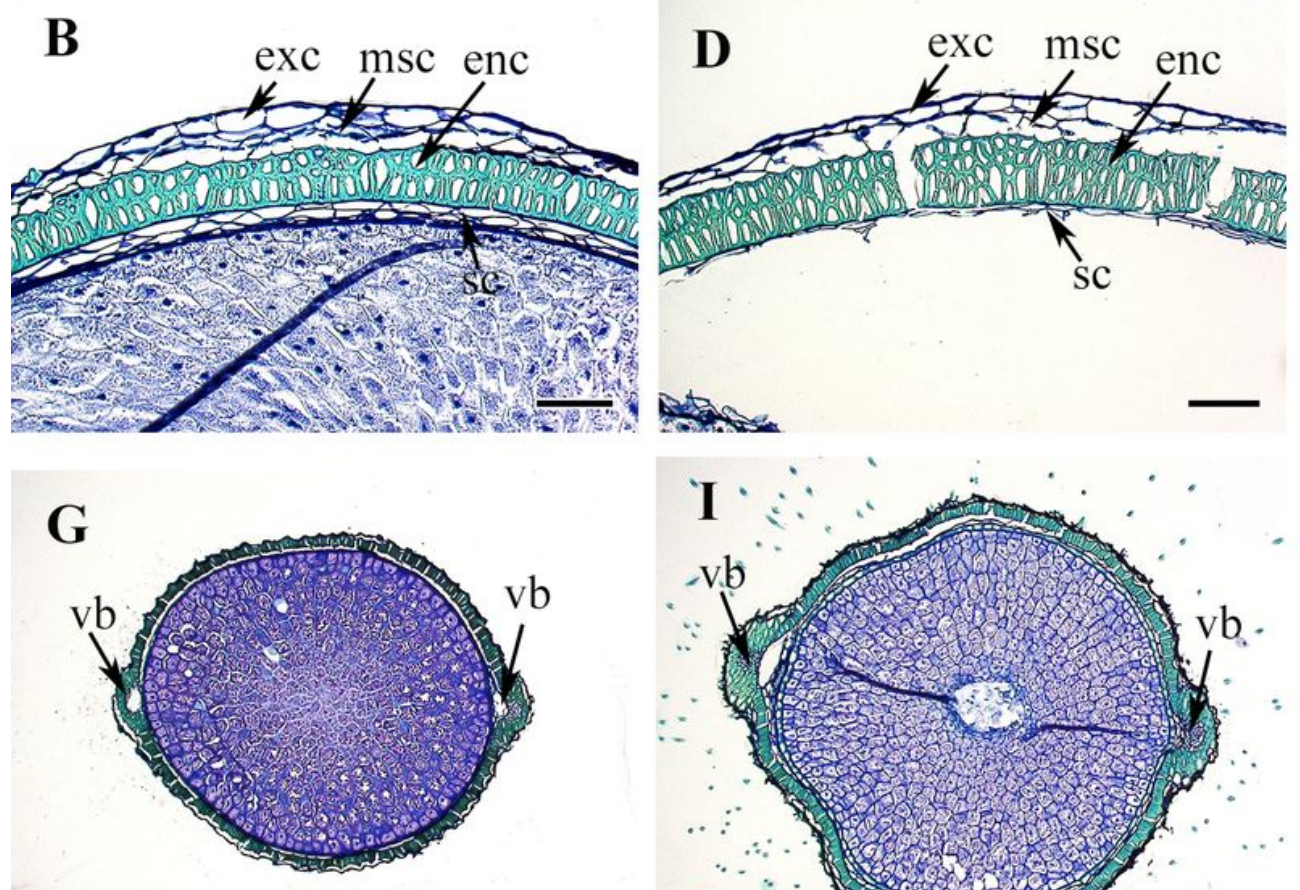

\section{Datase}
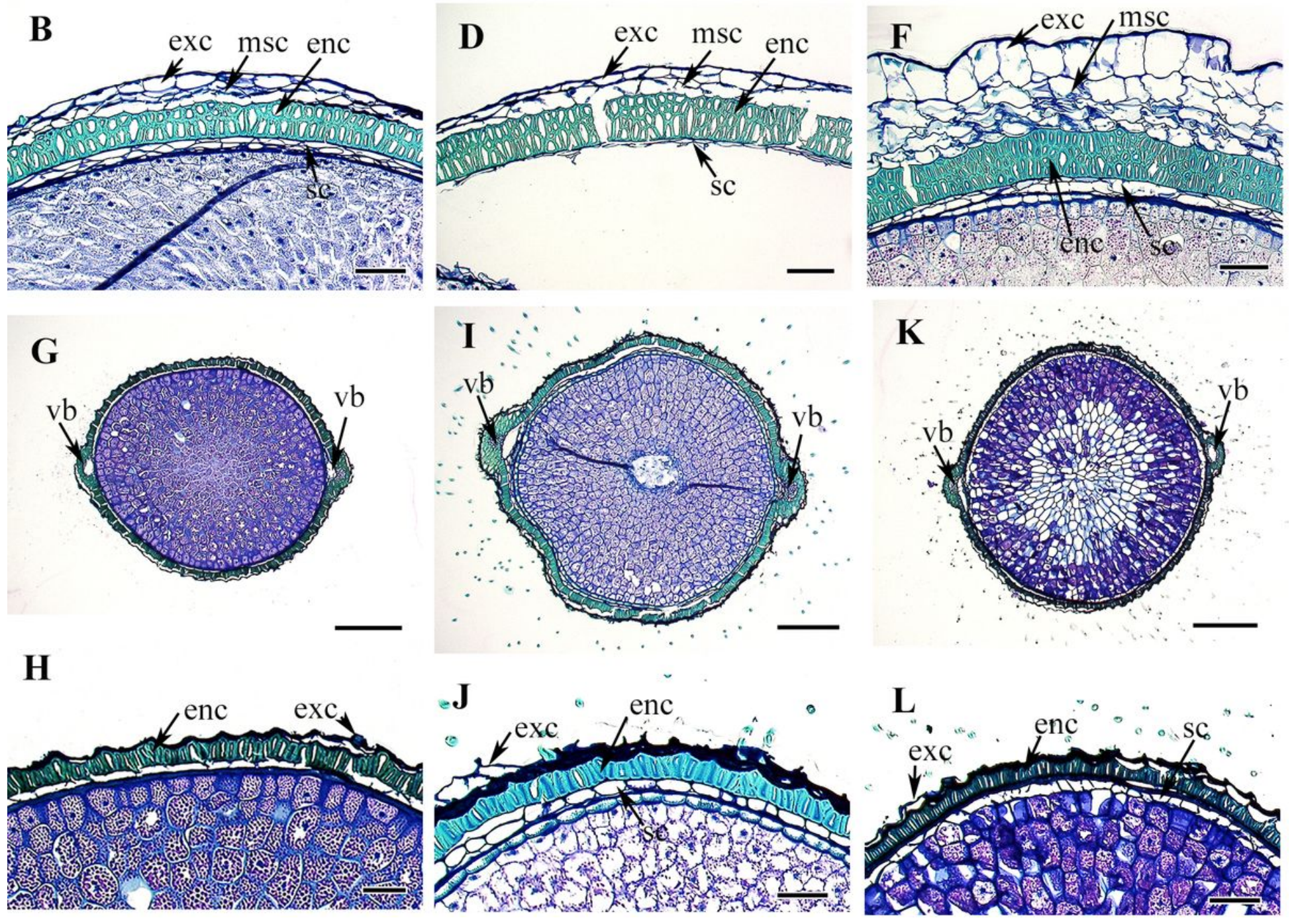

Figure 5

Cross section of Hepatica and Pulsatilla achenes. A, B. H. asiatica. C, D. H. insularis. E, F. H. maxima. G, H. P. davurica. I, J. P cernua. K, L. P. tongkangensis. Scale bars: A, C, D $=0.75 \mathrm{~mm} ; \mathrm{G}, \mathrm{I}, \mathrm{K}=0.25 \mathrm{~mm}$; B, D, F, H, $\mathrm{J}, \mathrm{L}=0.1 \mathrm{~mm}$. Abbreviations: en, endocarp; end, endosperm; ex, exocapr; ms, mesocarp; sc, seed coat; vb, vascular bundle. 


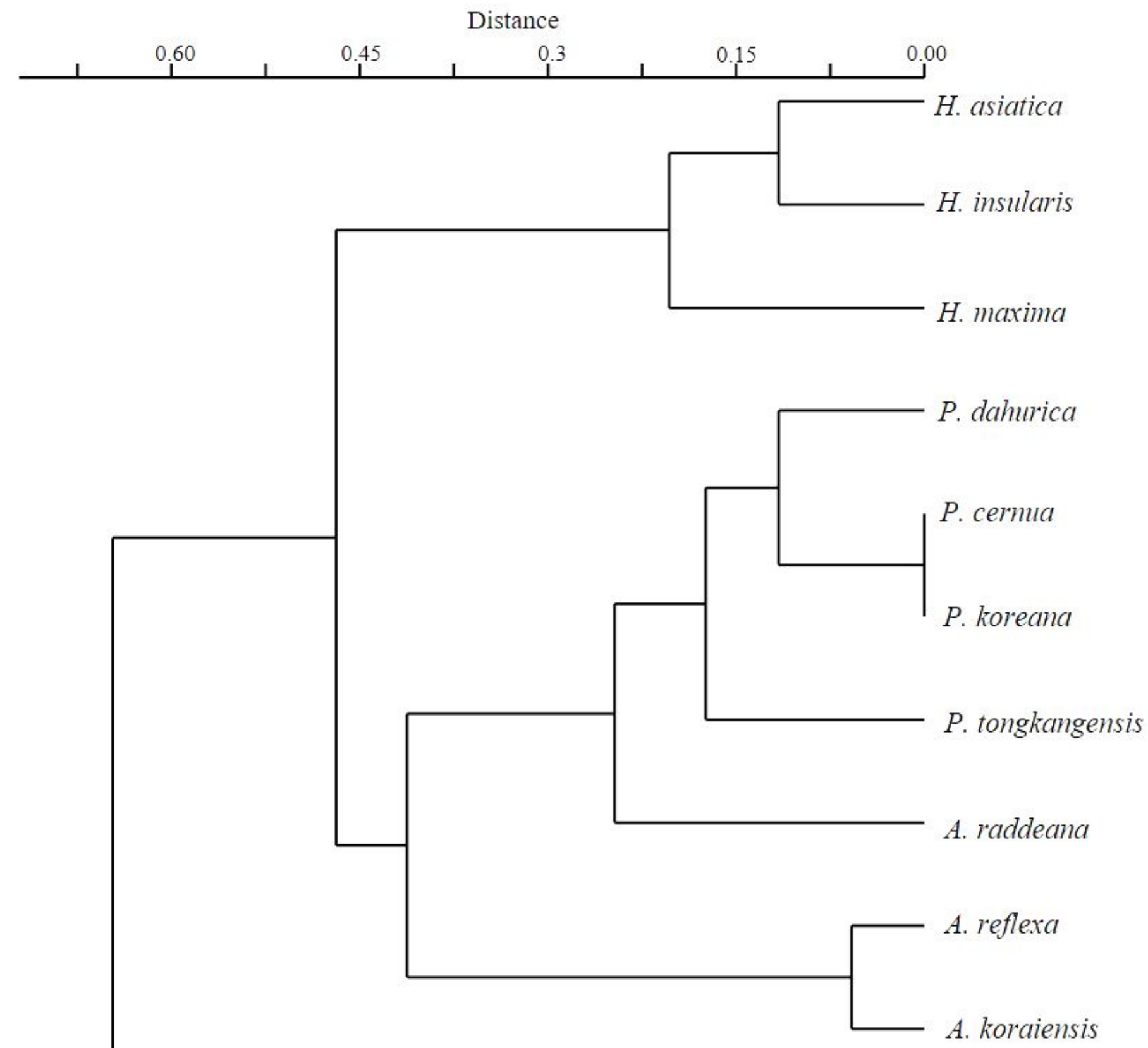

\section{Figure 6}

UPGMA cladogram based on achene features of Anemone, Hepatica, and Pulsatilla.

\section{Supplementary Files}

This is a list of supplementary files associated with this preprint. Click to download. 
- Supplementartydata.doc

Page 21/21 